feet behind me.

For that summer and the next he would meet the car at the bottom of the hill and run behind it up the driveway to the cottage. With just my wife and I present he would get to within 2 or 3 feet of us, with more people around he would draw progressively further away. A few times he allowed me to lift him on my outstretched hand but was more relaxed when he walked up my arm to my shoulder, occasionally jumping up onto my head.

When arriving at the cottage very early the third spring he did not appear as we rolled down the hill. To this time we have not seen either him or any Ruffed Grouse in the area.

\section{UNSEEMLY BEHAVIOR OF HOUSE SPARROW}

FRANK BRAZIER, 2657 Cameron Street, Regina, Saskatchewan, S4T 2 W5.

During the afternoon of 12 May 1980 , I saw a very young House Sparrow sitting quietly on a tree limb close to the main trunk. Its bright yellow gape indicated that it had left the nest only recently. I was sitting no more than 10 feet from it at eye-level, and had a three-quarter profile view; its head was to my left. Its sex, of course, was unknown.

While I watched a male House Sparrow, in full breeding plumage, flew to the branch about a foot above the baby, paused for a few seconds, then dropped on to the back of the youngster and performed, briefly, what appeared to be an attempt at copulation. It then resumed its perch above the baby bird.

A few seconds later the mother sparrow arrived and fed her young one, then flew away. The male also departed.

At no time did any of the participants appear to be excited. The baby bird did not make any of the characteristic food-begging gestures which usually include wing-shivering. This latter act is imitated, by the female House Sparrow when she solicits the male's copulatory attentions. Neither did the baby utter the begging food calls which the female, at mating time, also imitates. If the baby had confused the male by giving the begging food calls or the wing-shivering display his reaction would have been understandable as the plumage difference between the young and the female is slight, and he was perched above and slightly behind the baby and perhaps could not see the yellow gape.

I could find nothing in SummersSmith remotely approaching the male's inexplicable act. ${ }^{1}$

'SUMMERS-SMITH, J. D. 1963. The House Sparrow, Collins, London.

\section{SASKATCHEWAN CHRISTMAS BIRD COUNT}

From Saturday, 20 December 1980 to Monday, 4 January 1981, inclusive. Count area should be a circle, $24 \mathrm{~km}$ (15 miles) in diameter. This year, bird count forms will be sent to all compilers who submitted counts for Christmas 1979. Anyone else who wishes to send in a count, please write for a form to: Mrs. Mary I. Houston, 863 University Drive, Saskatoon, Sask. S7N $0 J 8$.

Reports should be sent as soon as possible after the count (by January 15,1981 at the latest) to the above address. 